\title{
Generation the Strategy of Financial Stability at the Enterprises of Textile Industry
}

\author{
Muminova Nargiza Makhsudjonovna, Maxmudova Dilfuza Marlenovna
}

\begin{abstract}
This paper investigates major points of the generation the strategy of financial stability at the enterprises of textile industry. Examples of the financial stability were seen in the case of Uzbekistan. On this case, research works were based on conducted features of the enterprises of textile industry. Finally, it concludes with both outcomes and shortcomings as the whole.
\end{abstract}

KeyWords - Generation, strategy, financial stability, enterprises, textile industry

\section{INTRODUCTION}

At the present stage of the development of the textile industry in the Republic of Uzbekistan an increasing number of the enterprises of this branch of economy recognize need to develop perspective financial activity on the basis of the scientific research allowing to carry out the forecast of its directions according to overall objectives of the enterprise's development and the changing conditions of the external financial environment(Kalpakjian\& Schmid, 2014).

The productive instrument of the development the perspective financial activity at the enterprise subordinated to realization the purposes of its general development in the conditions of essential changes in the field of state regulation of market processes, macroeconomic indicators, structure of the financial market represents financial strategy(Madritsch\& Ebinger, 2011; Muhammad et al., 2012).

That is, the enterprises must not be concentrated only on the current state, but also develop the expected directions of its development which will allow reacting to the changes of external and internal environment. Regulation and use of financial resources allow to maximize the profit in a shortterm period and to support the condition of financial stability in the long-term period that is a basis of effective strategy of financial stability of the enterprise(Bobur \& Alimova, 2017; Braga, Fink, \& Sepulveda, 2000; Fallon, 2015; World Business - Economics and Finance Conference, 2011)

Revised Manuscript Received on July 25, 2019

Muminova Nargiza Makhsudjonovna, Ph.D, Corparive governance Department Tashkent Institute of Textile and Light Industry Maxmudova Dilfuza Marlenovna, Senior teacher, Corparive governance Department Tashkent Institute of Textile and Light Industry

\section{THEORETICAL BACKGROUND}

Therefore, ensuring the financial stability is among the priority directions of its activity. Change of consumers' demand, expansion of opportunities for business, development of means of communication and connections, wide extension of modern technologies, change of the role of human resources and other factors have increased the value of formation the strategy of financial stability of the enterprise. It is in this connection expedient to define the place of financial strategy of sustainability in the financial strategy of the enterprise(Ley, Krumpelt, Kumar, ..., \& 1996, n.d.; Muhammad et al., 2012; Onder, 2002; Rao \& Yap, 2011).

Realization the strategy of financial stability is possible only at complex interaction with all directions of financial strategy of the enterprise: so, for example, the size of own, loan and raised enterprise assets depends on the strategy of formation of financial resources; investment strategy allows using effectively available funds of the enterprise, promoting the increase the level of its financial stability.

The strategy of improvement the quality of financial management is connected with regulation the quality of financial management, and the strategy of ensuring the financial safety is directed to the maintenance the indicators of financial stability of the enterprise in the course of realization the financial strategy of the enterprise in general. To achieve the results under the influence of factors of the external environment organizations need to react more quickly to the changing market conditions, than to the competing organizations, improving the positions on quality, the assortment and the price of production or services(Frank, Lueger, \& Korunka, 2007).

As practice shows, it is difficult to compete without operate obtaining information concerning the competitors, market condition and new preferences of consumers. At the same time all actions must be coordinated and concentrated on achievement of certain long-term goals.

For this purpose each textile enterprise needs to form its own strategy of financial stability which will define a current state of financial resources and the direction of their distribution and use in the future. Therefore, the corporation must define the strategy's direction of financial stability depending on the level of financial stability which has developed at the time of strategy formation. This direction can be connected either with increase, or with maintenance at the previous level of financial stability of the enterprise(Agnew, 1997; 
Dolliver, 2015; Heyneman \& Young, 2006).

Having generalized theoretical approaches of researchers and based on practice of organizations' activities, we will formulate the following definition of strategy of financial stability of a textile enterprise: it is the program of stage-bystage actions and activities provided by the financial strategy of the enterprise and directed to increase and maintenance the level of its financial stability. Content of the strategy of financial stability of an enterprise consists in creating for it a potentially flexible position allowing this economic subject to achieve goals despite negative influence of factors of the internal and external environment(Management, 2010; Muhammad et al., 2012; Rasanayagam, 2011).

\section{MAIN WORK}

he research on condition of financial stability of the enterprises of textile and light industry included in JCS "Uztekstilprom", presented in Chapter 2 of the thesis indicated that financing of their activities on an interval of 2012 - 2016 was carried out approximately in an identical proportion due to the use of own and borrowed raised funds.Ensuring the financially steady activity of a textile enterprise assumes the existence of a constant flow of reliable, full and timely information (the internal reporting, data of market researches) which gives the chance to make decisions in due time and to accumulate data about the external environment at the enterprise.

Internal information is formed as a result of economic entity's activity and constantly changes under the influence of transformation the main indicators and is directed to full reflection of the current activity of the enterprise, including production, marketing, financial, personnel and other capabilities.

Studying the external environment of an organization is carried out in three directions: an assessment of changes of the external environment making an impact on various parties of financial stability strategy; a research of the factors which negatively influence the realization of the strategy of financial stability at the enterprise; definition of the factors giving more opportunities to achieve strategic objectives of the enterprise by updating the plan of financial stability strategy.

The analysis of the external environment gives the chance to estimate results of activity of the enterprise, to predict the prospects of development, to make the action plan in case of approach the unforeseen circumstances, to create the actions allowing preventing emergence of possible threats.In the strategic financial analysis the opportunities and threats, interfering the development of the enterprise, are grouped in system of PEST analysis:

- P - political and legislative environment;

- E - economic environment:

- S - social and cultural environment;

- T - technological environment .

The legislative, political, social and technological environment makes impact on formation and realization the strategy of financial stability at the enterprises. The legislative and political environment is connected with state regulation of the financial market, monetary circulation in the country, the state policy of separate branches. The correct legislative basis of the state leads not only to financial development of the enterprises of textile industry, at the expense of the provided privileges and preferences from the state, but also to attraction of foreign investments and increase in the export which by the end of 2016 had grown up to $\$ 1,1$ billion. And this with the fact that in the conditions of crisis the price of raw materials and main types of textile production considerably fell(Salzarulo, Krehbiel, Mahar, \& Emerson, 2012).

This tendency of development besides the rational organization of production and work has been caused by numerous privileges and preferences, provided by the legislation of the Republic of Uzbekistan.For instance a large number of privileges and privileges was applied to the joint and foreign ventures:

- It was possible to buy cotton and fiber with a $15 \%$ discount and by installments for a period of 90 days.

- The enterprises were exempted from taxes and fees in the state budget, except value added tax.

- The enterprises of the textile industry were exempted from customs payment of the imported equipment, accessories and the raw materials which were not produced in the republic till January 1, 2016.

- The right to reduce taxable base by the sum of the funds allocated for a modernization of hardware.

- Remission of the property tax with a five-year term for the new enterprises.

- The enterprises exporting more than $80 \%$ of production were exempted from payment of tax duties.

Above-mentioned privileges and preferences had led to increase in net profit at the enterprises of the textile industry for $24 \%$ for the end of 2016, however, did not provide to use fully all the investment opportunities and therefore attraction of the foreign capital in the textile industry happened not so actively in comparison with the competing export countries. With a view to furthering the well-being the financial stability of the textile enterprises it is necessary to realize the tasks, the main of which is the implementation of 132 investment projects on production of finished export-oriented textile and sewing and knitted goods for the total amount of 2204,6 mln. US dollars to the organization, modernization and reconstruction of the enterprises. These projects will be carried out not only on the basis of own means and the credits of commercial banks, but also due to foreign investments which specific weight makes $36,2 \%$ in the total cost of theprojects.

The main investors, making up 44,4\% of total amount of the realized investments for 2017 - 2019, are Netherlands with a total amount of $305 \mathrm{mln}$. US dollars, Singapore $(21,4 \%)$ with the gross volume of investment of $147,1 \mathrm{mln}$. US dollars and Switzerland $(15,5 \%)$ with the sum of investments on $106,5 \mathrm{mln}$. US dollars. 


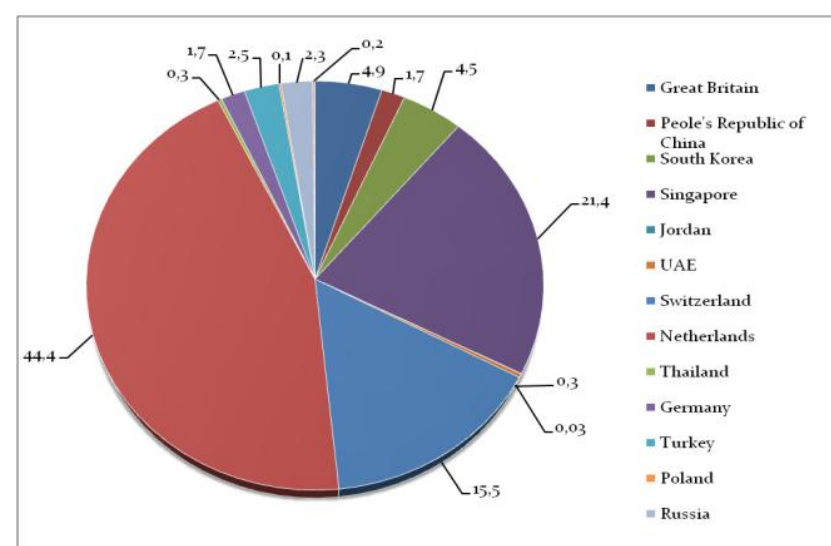

Figure 1 - Shares of the countries in a total amount of foreign investments into the textile industry for 2017 - 2019

The technological environment in the textile industry makes strong impact on formation and realization the strategy of financial stability at the enterprises of textile industry, impact on strategic development which is manifested in the form of innovations, new financial instruments and technologies, in this regard for it is planned for 2017 - 2019 a modernization of 10 textile enterprises for the total amount of $58,3 \mathrm{mln}$. US dollars, of them $8,4 \mathrm{mln}$. US dollars relate to the own means, $34,5 \mathrm{mln}$. US dollars- to the credits of commercial banks and 15,4 mln. US dollarsforeign investments.

Social and cultural impact on financial activity and financial stability of corporation is shown in the educational and cultural level of the population, its relation to the undertaken market reforms.

Direct impact from factors of the external environment on the enterprises of the textile industry is made by the competitive environment which research is carried out in several steps:

- the analysis the objectives of rival organizations;

- an assessment the strategy of the competing organizations;

- a research on the directions of the development of the competing organizations and branches in which competitors function;

- identification and studying of strong and weak positions of competitors.

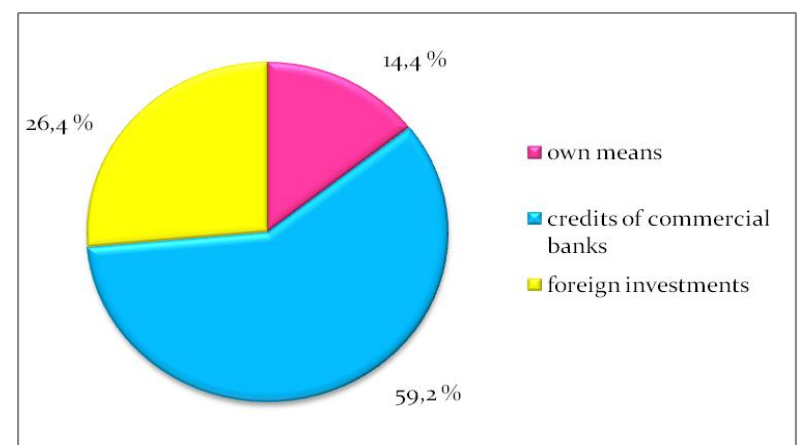

Figure 2- Financing sources of projects on modernization the textile enterprises for the period of 2017 - 2019

The analysis of the external environment allows revealing threats and opportunities which the organization can face as a result of influence of external factors.

\section{RESULTS}

From completeness, reliability and timeliness of information, and also the order of its collecting, processing and storage the effectiveness of the strategy realization on the financial stability is defines at textile enterprise.

Thus, financial controlling is the tool in control of the strategy of financial stability providing development and implementation of strategic decisions on a number of the directions in the conditions of constantly changing external environment:

- coordination of financial decisions on achievement of strategic objectives;

- control of changes in the external environment;

- formation of the strategic approaches adapted to conditions in which the enterprise functions;

- effective use of the advantages which are available for corporation and creation of new opportunities of sustainable development in a long term.

\section{CONCLUSION}

Formation of strategy of financial stability has a great importance in ensuring sustainable development of a textile enterprise. Process of development the strategy of financial stability includes definition of the most effective directions according to the solution of goals which is followed by search and an assessment of alternative versions of possible strategic financial decisions on criterion of increase in level of financial stability of enterprises of textile industry. The strategy of financial stability considers changes of conditions of external and internal environment in process of financial activity and in due time reacts to these influences

\section{REFERENCES}

[1] Agnew, N. (1997). Conservation of ancient sites on the silk road. .. Conference on the Conservation of Grotto Sites, ..., (October), 395405. https://doi.org/10.1017/CBO9781107415324.004

[2] Bobur, S., \& Alimova, M. (2017). Systematic approach to the development of innovative tourism. Case of Uzbekistan regions. South Asian Journal of Marketing \& Management Research.

[3] Braga, C. A. P., Fink, C., \& Sepulveda, C. P. (2000). Intellectual Property Rights and Economic Development. The World Bank. https://doi.org/10.1596/0-8213-4708-X

[4] Dolliver, D. S. (2015). Evaluating drug trafficking on the Tor Network: Silk Road 2, the sequel. International Journal of Drug Policy, 26(11), 1113-1123. https://doi.org/10.1016/j.drugpo.2015.01.008

[5] Fallon, T. (2015). The new silk road: Xi jinping???s grand strategy for eurasia. American Foreign Policy Interests, 37(3), 140-147. https://doi.org/10.1080/10803920.2015.1056682

[6] Frank, H., Lueger, M., \& Korunka, C. (2007). The significance of personality in business start-up intentions, start-up rialization and business success. Entrepreneurship and Regional Development, 19(3), 227-251. https://doi.org/10.1080/08985620701218387

[7] Heyneman, S., \& Young, A. De. (2006). The challenges of education in Central Asia. Retrieved

[8] Kalpakjian, S., \& Schmid, S. (2014). Manufacturing engineering and technology. Retrieved from https://www.researchgate.net/profile/Vijay_Sekar2/publication/2621 56319_Manufacturing_Engineering_and_Technology/links/00b4953 6c9c352428b000000.pdf

[9] Ley, K., Krumpelt, M., Kumar, R., ... J. M.-J. of M., \& 1996, undefined. (n.d.). Glass-ceramic sealants for solid oxide fuel cells: Part I. Physical properties. Cambridge.Org.

[10] Madritsch, T., \& Ebinger, M. (2011). Research journal of economics, business and ICT. Research Journal of Economics, Business and ICT (Vol. 2).

Retrieved

$$
\text { from }
$$




\section{Generation the strategy of financial stability at the enterprises of textile industry}

https://journals.cz/index.php/RJEBI/article/view/190

[11] Management, B. (2010). CUSTOMER-ACCEPTABLE VARIATION OF E-COMMERCE QUALITY CHARACTERISTICS Natalija Guseva. Journal of Business Management, (3), 140-146. Retrieved from http://search.ebscohost.com/login.aspx?direct=true\&db=bth\&AN=5 $5981148 \& \operatorname{login}$. asp \& site $=$ ehost-live \&scope $=$ site

[12] Muhammad, S., Iqbal, J., Muneer, S., Jahanzeb, A., Iqbal, S. M. J., \& Saif-ur-Rehman. (2012). A Critical Review of Capital Structure Theories. Information Management and Business Review, 4(11), 553-557. Retrieved from http://search.proquest.com/docview/1326738751?accountid=14872

[13] Onder, D. E. (2002). A new housing group for sub-residential area in Samarkand: A morphological comparison. Cities, 19(5), 327-339. https://doi.org/10.1016/S0264-2751(02)00041-0

[14] Rao, S., \& Yap, F. (2011). Mechanical vibrations. Retrieved from http://engineering.ju.edu.jo/ar/Arabic/Lists/Courses/Attachments/14 7/MECH-0904582-Vibration and Noise Control -Sep-2016-Fall.pdf

[15] Rasanayagam, J. (2011). Informal economy, informal state: the case of Uzbekistan. International Journal of Sociology and Social Policy, 31(11/12), 681-696. https://doi.org/10.1108/01443331111177878

[16] Salzarulo, P. A., Krehbiel, T. C., Mahar, S., \& Emerson, L. S. (2012). American Journal of Business. American Journal of Business International Journal of Lean Six Sigma International Journal of Productivity and Performance Management, 27(5), 113132. Retrieved from https://doi.org/10.1108/19355181211274433\%0Ahttps://doi.org/10. $1108 / 19355181211274433 / /$

[17] World Business - Economics and Finance Conference. (2011). DATES: 26 \& 27 September 2011 VENUE: Novotel Hotel, Bangkok, Thailand. 2011/08/29. https://doi.org/10.1016/02621762(95)90767-X 